University of Warwick institutional repository: http://go.warwick.ac.uk/wrap This paper is made available online in accordance with publisher policies. Please scroll down to view the document itself. Please refer to the repository record for this item and our policy information available from the repository home page for further information.

To see the final version of this paper please visit the publisher's website. access to the published version may require a subscription.

Author(s): Mark Harrison

Article Title: Counting Soviet Deaths in the Great Patriotic War:

Comment

Year of publication: 2003

Link to published version: http://dx.doi.org/

10.1080/0966813032000123097

Publisher statement: None 


\title{
Counting Soviet Deaths in the Great Patriotic War: Comment*
}

\author{
Mark Harrison** \\ Department of Economics \\ University of Warwick
}

\begin{abstract}
Michael Haynes has pointed out that the conventional methodology for estimating the number of Soviet war deaths provides only a lower limit. It calculates wartime "excess" deaths, assuming that no one was killed by the war who would normally have died anyway; this sets a lower bound on the number of real war deaths that may have resulted directly or indirectly from enemy action. Where is the upper limit? Haynes proposes the 16 million total of "normal" deaths as a measure of the maximum possible downward error when real Soviet war deaths are estimated by the excess mortality method. The possible margin of downward error arising from this method can be calculated and is not 16 million but approximately 1.9 million.
\end{abstract}

* Published in Europe-Asia Studies 55:6 (2003), pp. 939-44.

** Mail: Department of Economics, University of Warwick, Coventry CV4 7AL, UK. Email: Mark.Harrison@warwick.ac.uk. I thank Stephen Broadberry, R.W. Davies, Michael Haynes, and Peter Law for comments on previous versions. 


\section{Counting Soviet Deaths in the Great Patriotic War: Comment}

Michael Haynes (2003) has recently noted that existing calculations of Soviet war deaths are based on the concept of excess mortality. He suggests that reliance on estimated "excess" deaths associated with wartime conditions may lead us to underestimate "real" Soviet war deaths, defined as "deaths that are directly or indirectly related to the war". He argues that excess deaths set a lower bound on the number of real war deaths, and that the upper bound is set by the total of actual deaths. In the Soviet Union total actual deaths between July 1941 and June 1945, possibly including net wartime emigration, have been estimated at approximately 42.7 million; this is the upper limit on the possible demographic loss arising from the war. Excess wartime deaths, again perhaps including net wartime emigration, have been estimated at 26.6 million, and this is the lower limit. Haynes concludes that the real demographic loss therefore "lies somewhere between 26.6 and 42.7 million".

This is a welcome and valuable intervention: it has usefully raised issues that have been understated in the recent literature (Andreev et al., 1990; Wheatcroft and Davies, 1994; Ellman and Maksudov, 1994; Krivosheev et al., 2001). When, because of a lack of records, we do not observe real war deaths directly, we must infer them indirectly. The conventional methodology for doing so is deliberately conservative, and Haynes is correct to point out that it sets only a lower bound on real war deaths. However, it is wrong to conclude that the real Soviet demographic loss may have been any number between 26.6 million and 42.7 million. The true upper limit can easily be calculated and is much closer to the lower figure that may appear at first sight.

The underlying data are those provided by an expert commission of USSR Goskomstat that Gorbachev set up in 1989 (Andreev et al., 1990). They can be relied upon except for two principal sources of uncertainty: how to account for net wartime emigration, that is, for those who could not be counted in the population remaining at the end of the war not because they had died but because they had left the country; and the extent of the unmeasured wartime dip in fertility, which reduced wartime deaths by reducing live births and thus the number of babies at risk of dying before the war ended. Net wartime emigration has been estimated at around 2.7 million and it seems likely on balance that the Goskomstat demographers included them in the 26.6 million (Ellman and Maksudov, 1994). ${ }^{1}$ Our uncertainty over wartime fertility is also hard to reduce. However, neither affects the principle that is presently at stake.

For the sake of simplicity and so as to focus clearly on the issue of mortality, I will differ from Haynes in presuming that wartime emigrants are in fact included in the Goskomstat estimates of prewar population and actual wartime deaths and should be deducted from them; otherwise I will share Haynes's presumption that the Goskomstat demographers did their job well and their figures are reliable. I will first consider the sources of wartime mortality among those already born and living on Soviet territory in mid-1941, and I will subsequently consider implications for wartime infant mortality.

${ }^{1}$ This matter was raised in a recent H-Russia discussion of Soviet excess deaths, 1941 to 1945, opened on 6 February 2003, closed on 27 February, and archived under http://www2.h-net.msu.edu/ russia/. I note in particular Jon Petrie's helpful comment posted on 23 February. 
The Soviet population of mid-1941 has been counted at 196.7 million. However, Maksudov has put net wartime emigration at 2.7 million, and the great majority of these must have been living when the war broke out. Therefore, of those living on Soviet territory before the war, 196.7 $-2.7=194$ million were actually available as a pool from which the postwar population could be drawn. However, only 159.5 million were still living on the same territory in mid-1945, giving a total mortality amongst the prewar population of $194.0-159.5=34.5$ million.

The excess mortality method of estimating war deaths as it is conventionally applied then computes how many would have been carried off as a result of normal mortality processes over four years in the absence of war, and arrives at a figure of 11.9 million. Deducting these from total deaths suggests excess wartime deaths among those alive in July 1941 of $34.5-11.9=22.6$ million. Figure 1 illustrates this computation.

Figure 1. The Soviet Population of July 1941, as of June 1945: millions

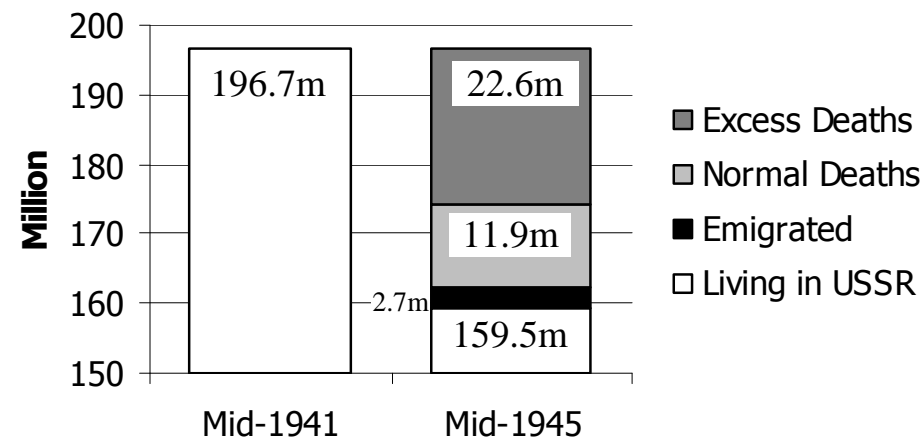

Source: Andreev et al. (1990); Ellman and Maksudov (1994: 672-3).

To understand what has been done here, consider the risks of my prospective death from various causes during the coming period. Let $d$ stand for the probability of my death arising from normal or peaceful processes in the absence of war, while $k$ is the probability of my being killed as a direct or indirect result of enemy action if war breaks out and in the absence of other causes. Given peace, $k$ is immaterial and I risk only $d$. Given war, however, these probabilities interact to mitigate each other; thus my prior risk of dying taking into account that I may be killed first falls to $d \cdot(1-k){ }^{2}$ By the same reasoning my "excess" war risk, the probability that I will be killed on top of the chance that I may die anyway, is only $k \cdot(1-d)$.

My overall survival chances can be computed as $(1-d) \cdot(1-k)=1-d-k+d \cdot k$; thus my total risk of dying from all causes, $m$, is not the sum of $d$ and $k$ but the lesser risk $m=d+k-d \cdot k ; m$ is less than $d$ and $k$ taken together by the value of their interaction $d \cdot k$, which stands for the fact that the two risks must compete for victims and therefore to some extent overlap each other. It is only after the event that the causes of death turn out to have been mutually exclusive. If I am killed first I cannot also die, and conversely: my life can only be ended once. Thus my combined mortality risk $m$ can be written in two ways: $d+k \cdot(1-d)$, my normal risk in the

\footnotetext{
${ }^{2}$ In Britain in 1944 age-specific mortality not attributable to war operations was generally less than in 1938 (Titmuss, 1950: 521, 524), and this is sometimes taken to suggest that civilian health improved under wartime food rationing and welfare provisions, but some part of this effect should be attributed to the simple fact that in wartime traditional causes of death must compete with new ones.
} 
absence of war, plus my "excess" war risk; or $k+d \cdot(1-k)$, my war risk assuming I do not die, plus my normal risk taking into account that the war may kill me first.

The interaction of mortality risks is at the core of the problem of Soviet war deaths. This is because, when we know the prior risks of death generally but fail to observe the causes of each specific death after the event, the interaction creates uncertainty: we know people must have died of either $x$ or $y$, but they cannot have died of both, and we do not know exactly which was the cause in each case. In most contexts that are familiar to us the interaction of mortality risks does not matter: for example if my chances of dying from heart disease and cancer in the next year are each one per cent, then my combined risk is $2 \times 0.01+0.01^{2}=1.99$ per cent, not 2 per cent but so close to it that no one can much care about the difference. When millions of people experience high risks over long periods their interaction becomes quantitatively important and also defines the scope for uncertainty in attributing deaths to specific causes when the causes themselves are not observed. However, even in this case the scope for error is strictly limited.

To apply this to the present matter, when we cannot observe real war deaths directly we may estimate them in two ways that give an upper and a lower bound respectively. The lower bound is set by the conventional excess mortality method: first, compute the number of normal deaths conditional upon peace, $d \cdot P$ where $P$ is the prewar population. Subtract this from total deaths, $(d+k-d \cdot k) \cdot P$. This gives us the least number that must have been killed, allowing for the full peacetime risk that they may have died first: $k \cdot(1-d) \cdot P$, which is therefore a lower bound on real war deaths. This is the excess mortality concept employed by the Goskomstat demographers.

For the upper bound on real war deaths, first compute the number of normal deaths, not conditional upon peace but allowing fully for the wartime risk that each may be killed first: $d \cdot(1-k) \cdot P$. Subtracting this from total deaths gives us the maximum number that might have been killed if normal risks were absent: $k \cdot P$, which sets a ceiling on real war deaths. Thus $d \cdot(1-k) \cdot P$ is the excess of total deaths over the true ceiling on war deaths and is therefore also the difference between Haynes and myself; on my argument these cannot have been true war deaths.

Intuitively, the upper and lower bounds are related to the timing of war deaths as follows. Suppose that for four years no one was killed by enemy action, and died only from normal causes; then all war deaths took place suddenly on the last day of the war, but clearly the war could then kill only those not already taken by normal causes. In this case actual war deaths would correspond to the lower bound, that is, to excess mortality conventionally computed. At the other extreme suppose that all war deaths took place on the first day of the war, leaving only the war survivors still at risk from normal causes. Now actual war deaths would corresponds to the upper bound. In practice, the war killed people continually, so the true figure for war deaths must be found between the lower and upper limits. Continually, but not smoothly: in fact, as figure 2 shows, the Red Army suffered half its total wartime losses in the first eighteen months. If we suppose that the distribution of civilian war deaths was similarly skewed, then the true figure for total Soviet war deaths should be found somewhat above the mid-point of the lower and upper limits. 
Figure 2. Soviet Military Losses, 1941 to 1945: thousands per quarter and cumulative, per cent of total

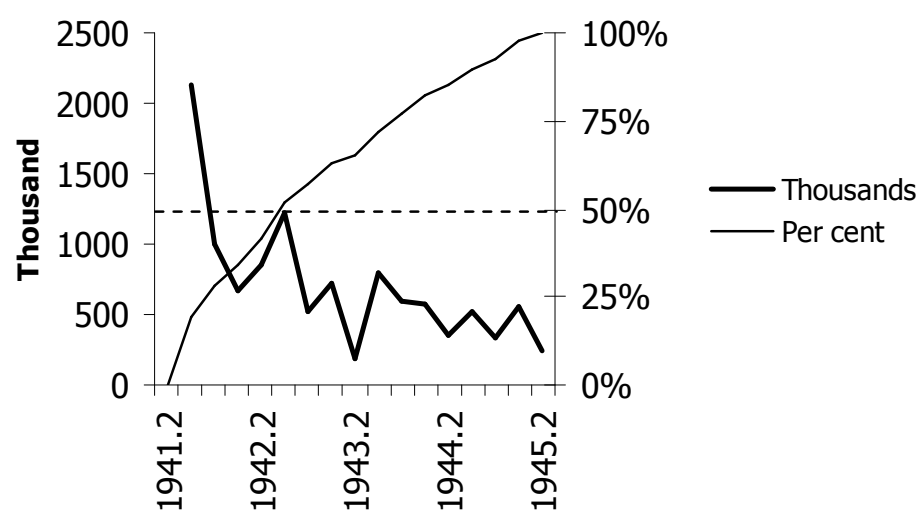

Krivosheev et al. (2001: 250). Losses are military personnel killed and died of wounds, disease, and accidents, missing, and captured. Of those missing and captured a proportion survived the war but it seems likely from what is known that deaths among prisoners were heaviest in the earlier stages of the war.

Where is the upper limit? The upper limit is simply $k \cdot P$. We do not know $k$ but, given the peacetime mortality risk $d$ and the wartime combined mortality risk $m$, we can estimate it from the proposition that $m=d+k-d \cdot k$, implying $k=\frac{m-d}{1-d}$. Table 1 shows the calculation and extends consideration to wartime births and infant mortality on the same lines.

Table 1. The Soviet Population, July 1941 to June 1945: Lives, Deaths, and Mortality on USSR Territory (millions and per cent)

\begin{tabular}{lrrr}
\hline & $\begin{array}{r}\text { Prewar Population, } \\
\text { less Net Emigration }\end{array}$ & $\begin{array}{r}\text { Wartime } \\
\text { Births }\end{array}$ & Total \\
\hline 1. Living or born & 194.0 & 16.4 &.. \\
2. Deaths & 34.5 & 5.4 & 39.9 \\
3. Total wartime mortality risk, $m$ & $17.8 \%$ & $32.9 \%$ &.. \\
4. Normal deaths in the absence of & & & \\
$\quad$ wartime causes & 11.9 & 4.1 & 16.0 \\
5. Normal mortality risk in the & & & \\
absence of wartime causes, $d$ & $6.1 \%$ & $25.0 \%$ &.. \\
6. Excess war deaths, lower bound & 22.6 & 1.3 & 23.9 \\
7. War mortality risk in the absence & & & \\
of normal causes, $k$ & $12.4 \%$ & $10.6 \%$ &.. \\
8. Excess war deaths, upper bound & 24.1 & 1.7 & 25.8 \\
\hline
\end{tabular}

Sources: Rows 1, 2, 4, and 6: as figure 1. Row 3: row 2, divided by row 1. Row 5: row 4, divided by row 1 . Row 6: row 2 , less row 4 . Row 7 , calculated as $k=\frac{m-d}{1-d}$ : row 3 less row 5, divided by 1 less row 5. Row 8: row 7, multiplied by row 1 .

Table 1 shows that the number of real Soviet war deaths amongst the prewar population that arose directly or indirectly from enemy action lies somewhere 
between 22.6 and 24.1 million; for war babies it lies between 1.3 and 1.7 million; for the population as a whole it lies between 23.9 and 25.8 million. Thus the maximum downward error in the currently accepted figure for real Soviet war deaths is not the 16 million range represented by all the adult and infant deaths that would have happened normally in the absence of war, but the 1.9 million range from the lower to the upper bound in the total column of table 1.

In summary Haynes has correctly argued that some of the 16 million deaths counted as "normal" in the Goskomstat figures were probably real war deaths due to enemy action. For illustration he proposes the case of Ivan, in reality killed by enemy action, but missing from the register of real war deaths: "had Ivan not been killed by a German sniper in 1941 he would have been knocked over by a Leningrad tram in 1943, had it been running in the event of no war" (Haynes, 2003: 305). The larger the number of Ivans missing from the Goskomstat figure for excess deaths, the greater the understatement of real Soviet war deaths.

It is helpful to be reminded that such Ivans existed, were in fact killed by the war, will be properly remembered by their families and communities as victims of the war, and should be numbered if possible among real war deaths. Therefore, Haynes suggests, we should add up to 16 million possible adult and baby Ivans to the excess deaths conventionally estimated. However, there is no reason why the possible Ivans should have faced any greater war mortality risk than the population as a whole; if anything, their war risk was less than the average precisely because they were at greater risk from normal causes of death that competed with war risks to carry them off and whittled their numbers down continually throughout the war period.

In this comment I have shown that the number of actual Ivans was, at most, less than two million. Of course this is a large number, sufficient to populate several medium sized cities. To define a possible margin of downward error of "less than two million" in our best estimate of Soviet war deaths is itself testimony to the terrifying scale of mortality on the eastern front.

To conclude, subject to some uncertainties about wartime emigration and fertility that cannot be resolved at present, real Soviet war deaths were somewhere between 23.9 and 25.8 million, with the true figure likely to be somewhat above the mid-point. Those who prefer round numbers may go for 25 million plus or minus a million. The suggestion that real Soviet war deaths could have ranged up to 40 million is categorically ruled out by logic and the evidence.

\section{References}

Andreev, E., L. Darskii, and T. Khar'kova (1990). "Otsenka liudskikh poter' v period Velikoi Otechestvennoi voiny." Vestnik statistiki, no. 10, pp. 25-7.

Ellman, Michael, and S. Maksudov (1994). "Soviet Deaths in the Great Patriotic War." Europe-Asia Studies, 46(4), pp. 671-80.

Haynes, Michael (2003). "Counting Soviet Deaths in the Great Patriotic War: a Note." Europe-Asia Studies, 55(2), pp. 303-9.

Krivosheev, G.F., V.M. Andronikov, P.D. Burikov, V.V. Gurkin, A.I. Kruglov, E.I. Rodionov, and M.V. Filimoshin (2003). Rossiia i SSSR v voinakh XX veka. Statisticheskoe issledovanie. Moscow: OLMA-PRESS.

Titmuss, R.M. (1950). Problems of Social Policy. History of the Second World War, United Kingdom civil series. London: HMSO.

Wheatcroft, S.G., and R.W. Davies (1994). "Population.” In R.W. Davies, Mark Harrison, and S.G. Wheatcroft, eds, The Economic Transformation of the Soviet Union, 1913-1945, pp. 57-80. Cambridge: Cambridge University Press. 